\title{
Gender and Tax
}

(forthcoming in GENDER AND POLITICS,

Jyl Josephson and Susan Tolleson-Rinehard, eds.

(M.E. Sharpe))

R. Michael Alvarez and Edward J. McCaffery

Olin Working Paper No. 99-11

\section{WORKING PAPER SERIES}

\section{Sponsored by the John M. Olin Foundation}

\author{
University of Southern California Law School \\ Los Angeles, CA 90089-0071
}


August 4, 1999

\title{
GENDER AND TAX
}

\author{
R. Michael Alvarez ${ }^{*}$ and Edward J. McCaffery ${ }^{* *}$
}

\section{INTRODUCTION}

Given the stakes involved, there has been surprisingly little empirical analysis of gender-based differences in attitudes towards specific aspects of taxation. Most of the literature on the so-called gender gap in political behavior has focused on the effects of gender on voting behavior in presidential or congressional elections (Chaney, Alvarez, and Nagler 1998; Mattei and Mattei 1998). ${ }^{1}$ When this literature has looked at attitudes on particular issues, it typically has been concerned with the impact of possibly genderdiverse policy preferences on voting behavior. Such analysis tends to use rather general attitudes towards questions of public interest as its input.

What is missing is a focus on gender-specific attitudes towards particular features of substantive law, independent of the impact on electoral outcomes, as a way of helping to explain certain persistent structural biases in the law. Tax is of particular interest and importance in this regard. The United States tax system is big and coercive and has deep effects on matters of concern to men and women, such as decisions to marry, to bear children, to be a one or a two-earner family, and so forth. Present law, for example, contains a pattern of "marriage penalties," whereby income taxes of twoearner couples increase on marriage, and "marriage bonuses," whereby taxes of oneearner couples decrease on marriage (McCaffery 1997). Such biases raise a host of questions for gender-oriented researchers. Do men and women share similar attitudes towards the relevant questions of tax policy and design? Are they equally likely to make their preferences known to lawmakers? Are they equally well-informed, or not?

\footnotetext{
* Associate Professor of Political Science, California Institute of Technology.

** Maurice Jones Jr. Professor of Law, University of Southern California Law School, and Visiting Professor of Law and Economics, California Institute of Technology.

Preliminary Draft: Please Do not Cite Without Permission
} 
Are there institutional barriers to greater gender-equity in tax? Do politicians target their advertising and educational outreach efforts, to attempt to appeal differently along gender-based lines?

This chapter points to work to be done in this important dimension of the interplay between gender and the law. It addresses two puzzles. The first is a theoretical one. Scholars have long postulated that women support redistributive tax policies more than men do (see for example Kornhauser 1987, see also Welch and Hibbing 1992). This assumption has found at least casual substantiation in national polling data suggesting that men are more likely than women to consider tax reduction as an important issue and in empirical analysis of the determinants of the gender gap in presidential elections (Chaney et al. 1998). This latter work has corroborated a longstanding theme in the empirical gender gap literature, namely that men tend to vote on the basis of narrow "pocket-book" issues, whereas women are influenced by broader questions of national and international social justice (Welch and Hibbing 1992), or】somewhat equivalentlyDthat women are more "compassionate" than men (Gilligan 1992). At the same time, recent work has found[not surprisingly Dthat the gender gap is a highly complicated social phenomenon, with no one "simple explanation" (Chaney et al., 333).

The assumption of women's greater support for progressive taxation, however, has been called into question. A recent survey suggests that when asked directly questions about the fairness of social spending and redistributive taxation, men and women show "little difference" in their attitudes (Turnier et al. 1996, 1315). This study draws support from recent polling data suggesting very similar attitudes of men and women towards broad questions of tax policy, and from the more general finding that men and women's policy preferences across a range of issues are not necessarily "substantially different" (Chaney et al., 314).

The second puzzle is one of practical politics. The substantive tax laws in the United States continue to reflect a strong bias against modern, two-earner familiesDa bias that can easily be understood as falling primarily on women (McCaffery 1997). Features 
such as mandatory joint filing under the income tax, severely limited tax relief for the costs of paid third-party child care, and the absence of a secondary-earner exemption under the social security system mean that working married mothers face extremely high marginal and effective tax rates. The average working wife sacrifices two-thirds of her salary to taxes and work-related expenses, and many women can even lose money, in a cash-flow sense, by working outside the home (Hanson and Ooms 1991, McCaffery 1997).

Principal features of substantive tax law causing this effect were put in place in the 1930s and 1940s. ${ }^{2}$ Since that time, there has been a dramatic increase in the incidence of working married mothers: Fewer than $10 \%$ of married mothers of young children engaged in paid work in 1940; more than $65 \%$ now do. ${ }^{3}$ A simple interest group model of politics would predict that as women have been both working more and exercising increasing political power, tax policy would change to lessen the structural burdens on working wives. But the trend has gone in precisely the other direction. The bias against two-earner families has become more severe as the structural features contributing to it have grown in magnitude. Meanwhile, women and feminist groups have not exerted significant influence over tax policy at the national level; indeed, salient issues such as the "marriage penalty" have been used by conservative social forces to continue to reward more traditional, single-earner families, as we explore further in Part III. B., below.

Our analysis in this chapter suggests a possible single answer to both of these puzzles. While there is reason to believe that men and women may indeed share similar primary or "first order" attitudes toward matters of tax, the weighting or "second order" preferences that men and women put on the importance of tax issues seems to have marked differences. This central finding reconciles the apparent paradox in the theoretical literature. Women and men will often answer direct questions about their attitudes toward matters of tax similarly, while continuing to show a marked gender gap in their actual voting behavior when tax is one of several issues to be considered. 
The results on first order preferences also appear to be subject to a strong framing effect, whereby answers to questions of tax are highly dependent on the form of the question (Kahneman and Tversky 1979). Linking tax cuts to decreased social spending, for example, seems to exacerbate a gender gap, because it draws attention to the more "sociotropic" attitudes of women, as opposed to the more "egocentric" attitudes of men (Welch and Hibbing 1992, Chaney et al. 1998). This is consistent with the salience or weighting hypothesis. Men are more likely to take their anti-tax attitudes as an "anchor," whereas women are more likely to take their pro-social spending positions that way. This divergent weighting of similar first order preferences leads to a gender gap when】but only whenDpositions are brought into trade-off.

The central finding also helps to explain the persistence of gender bias in practical tax policy. The divergent weighting or salience of tax issues for women and men suggests that it is a successful political strategy to pitch tax-oriented reforms towards men, and spending or social justice-oriented reforms towards women. Contemporary tax politics seems to bear out this hypothesis, and we conclude this chapter by outlining a future research agenda in this important area of the politics of gender in America.

\section{EMPIRICAL RESUlts AND ANALYSIS}

\section{Evidence on First Order Preferences}

Professors Turnier, Conover, and Lowery recently set out to test the hypothesis that men and women differed in their attitudes towards taxation. Using an extensive national telephone poll, Turnier and colleagues asked respondents to self-identify as men or women, Democrat or Republican, feminist or not. They asked a series of six questions on the fairness of supporting various causes with taxpayer money: care for abused spouses, the homeless, AIDS patients, and the like.

In order to determine attitudes towards tax, Turnier and colleagues asked two questions: 
The federal income tax is based on the principle that people with higher incomes not only pay more taxes but also a greater percentage of their income in taxes. Do you think this is very fair, somewhat fair, somewhat unfair or very unfair?

And:

Some say that capital gains $\square$ that is the profits people make from the sale of investment property, stocks and so forth $\square$ should be taxed at a lower rate than their income from wages and interest. Do you strongly agree, disagree, strongly disagree or have no opinion?

Based on their answers to these two questions, the authors studied the impact of gender on "tax fairness issues" and found it to be " very weak." More specifically, "by a very narrow margin, women indicated greater support for progressive taxation; however, by a slightly wider margin, men indicated greater support for eliminating capital gains preferences" (Turnier et al., 1312).

We put aside questions as to the study's methodology and conclusions, although we note that it is somewhat difficult to ascertain the "fair" position on a complex issue such as capital gains (for other criticisms of the Turnier study, see Kornhauser 1997). The Turnier study draws some support from a National Monitor Survey conducted in October, 1997. A national telephone poll of 1000 regular voters were asked a question on federal budget and tax policy, specifically whether they agreed with one of three positions:

Those that say a tax cut is a good idea but it should be across the board so that all taxpayers get a break;

Those that say that a tax cut is a good idea if it is targeted toward families and some eligibility is based on people applying that money 
directly toward savings for their children's education and their own retirement; or

Those who say that there is no need for a tax cut and that balancing the budget and assuring that federal programs are fully funded is more important.

The results of this question were sorted between men and women, and a further subset of working women was broken out. These results show virtually no gender gap, as Figure 1 illustrates:

\section{< <FIGURE 1 NEAR HERE〉>}

Across-the-board tax cuts were favored by $50 \%$ of men and $51 \%$ of women (48\% of working women); targeted tax cuts by $31 \%$ and $34 \%$ (36\%), respectivelyDshowing no significant gender gap.

This result that men and women are close in their general political preferences is a central finding of recent gender gap research (Chaney et al. 1998). The evidence on gender-based differentials in first order preferences still remains unclear, however, in part because of the framing effect we explore further below. Nonetheless, even assuming that the Turnier study is correct and that men and women share similar first order preferences about tax, the analysis of the empirical dimensions of political attitudes on gender and tax is far from over.

\section{Evidence on Second Order Preferences}

The same October, 1997 National Monitor Survey that generated Figure 1 included a question linking federal budget and tax policy: 
Do you feel that future budget surpluses should be used to reduce the deficit or used to continue to provide tax relief for working families?

Surprisingly, this question generated a pronounced gender gap among the very same pool of respondents, as Figure 2 shows:

\section{< FIGURE 2 NEAR HERE $>$}

Men preferred deficit reduction by 52 to $40 \%$; women in contrast preferred tax relief for working families, and by an even larger margin, 54 to $38 \%$. It is interesting to note that, in both questions, the preferences of working women and women were closely aligned. On the use of the surplus, working women were slightly more likely (57 to $36 \%$ as opposed to 54 to $38 \%$ ) to prefer tax cuts $\square$ but were far closer to all women than to men.

The stark reversal between Figures 1 and 2 shows that gender-based attitudes towards tax are susceptible to either the choice set, a framing effect, or both. Whereas the Turnier study and Figure 1 show that men and women sometimes have virtually indistinguishable primary attitudes towards questions of tax, Figure 2 shows that men and women can differ dramatically when a question of tax is posed in trade-off terms. This result might obtain because men and women attach different weights to the importance of tax vis a vis other issues, or because of a framing effect, with the precise determinants of either not altogether clear from the survey. Figure 1 reflects a choice between general, targeted (to families), and no tax reduction, and it generates a strong preference among both genders for general reduction. Figure 2 reflects a choice between targeted and no tax reduction, and it generates a pronounced gender gap, with women preferring the tax cut and men preferring the deficit reduction that comes from no tax cut. This might indicate a different ranking among choices for men and women, with men ranking the choices as:

general tax reduction $>$ deficit reduction $>$ targeted tax reduction for families 
and women ranking them as:

general tax reduction $>$ targeted tax reduction for families $>$ deficit reduction.

Including the general tax reduction option makes for no noticeable gender gap in Figure 1; eliminating it makes for the gap evident in Figure 2.

The reversal in Figures 1 and 2 might also have been caused, in whole or in part, from a framing effect generated by the fact that the question behind Figure 2 more clearly combines two distinct elements $\square$ tax reduction and social spendingDon one side of the question. Women supporting the tax cuts may be more concerned that some of the benefit of the surplus is going to help families, as opposed to more affirmatively supporting tax reduction per se. More precise research is needed to better understand the determinants of such inconsistent gender gaps as Figures 1 and 2 reflect.

\section{Analysis of 1996 Voter Data}

We wanted to get a better feel for the relative "politicization" of tax issues[how men and women weight the general issue of taxation in their political behavior. To do so, we turn to the most recent national electionDthe 1996 elections for President, U.S. Senate, and U.S. House. Tax was a very important issue in these campaigns. Bob Dole ran on a platform of across the board income tax rate cuts; other Republican candidates, picking up on the Contract with America and polling data suggesting that fundamental tax reform was a compelling political issue, were even more aggressive in calling for tax reform and reduction. Bill Clinton and the Democrats, in contrast, ran on a more moderate tax-cutting platform, emphasizing the need to preserve social spending on such programs as social security and education. The 1996 elections thus provide an excellent vehicle for examining the ways in which tax issues influence the political behavior of men and women. 
Our empirical analysis of the 1996 national elections uses exit poll surveys taken on election day; specifically, we use the Voter News Service General Election Exit Polls, 1996. The VNS Exit Poll was conducted in all fifty states and the District of Columbia on election day. In our work here we use only the national exit poll sample, not the separate state samples. The VNS national exit poll contained a wide variety of important survey questions, most specifically questions asking for the voter's presidential, Senate, and House candidate choices and for the voter's assessment of the most important issue facing the nation. Voters were given a list of seven issues and they could check one as being most important.

\section{< TABLE 1 NEAR HERE, OR REFER TO APPENDIX>>}

In Table 1 we provide the distribution of responses to this most important issue question, first for the complete sample (6832 voters), then for men (3184 voters) and for women (3552) voters. The issues are given in the left column of Table 1. In the "Full Sample" column, the percentages given are for the column $\square$ that is, they show the proportion of total voters who thought each issue was the most important one facing the nation. In the full sample, the most important issues were the "economy and jobs" (26.6\%), "social security and medicare" (17\%), and education (15.6\%). Taxes were said to be the most important issue by $4.8 \%$ of the voters in this exit poll.

The second two columns of Table 1 list the numbers of men and women voters, respectively, who said that each issue was the most important. In these columns, the percentages are for the row $\square$ that is, they show what proportion of voters identifying an issue as most important were men or women. For the three overall most important issues in the 1996 elections, as identified by the first column, we see that women were slightly more likely than men to say that the "economy and jobs" was the most important issue but that women were much more likely than men to list "social security and medicare" and "education" as most important. 
On the tax issue, men were much more likely than women to say that it was the most important issue $57 \%$ of those who ranked tax as the most important issue were men, significantly disproportionate to men's representation in the full sample. The relatively greater weight attached to taxes by men as opposed to women is consistent with a view of second-order ranking of preferences that has men being more egocentric, and women more sociotropic $\square$ tax being a classic "pocket-book" issue.

While men were more likely than women to think that taxation was the most important issue in the 1996 election, however, this does not necessarily imply that taxation was a less important component in voting decisions for women than for men. To assess the relative importance of taxation in political behavior for men and women, we estimated a series of voter choice equations, one for the presidential race, one for the Senate race (if there was one in the voter's state) and one for the House race. In these voter choice models, we had a binary dependent variable ( 1 for a Democratic vote, 0 for a Republican vote) which required the use of an appropriate statistical technique. Here we used binary probit models (see Chaney et al. 1998 for a fuller description of methodology).

For each race, we began by estimating the effect of a series of political issues, partisanship, ideology, economic perceptions, abortion preferences, and gender on vote choice for the entire sample. We then stratified the sample by gender, and reestimated the probit models for men and women separately. This procedure allowed us to examine the impact of each of these different factors on the voting decisions of men and women.

We report the results for the presidential election in Table 2, for the Senate in Table 3 and for the House in Table 4. Each column presents one probit equation, with the model coefficients given for each variable, followed by either one * or two ** to indicate differing levels of statistical significance and each coefficient's standard error. A positive number indicates a likelihood to vote Democratic; a negative, Republican. 


\section{<<TABLES 2-4 NEAR HERE, OR REFER TO APPENDIX〉>}

Beginning with the presidential voting equation set out in Table 2, we see that for the full sample the model performed as one would expect: Democratic voters were strongly significantly more likely to vote for Clinton, Republicans for Dole; liberals were strongly significantly more likely to support Clinton, conservatives to support Dole, and so on.

For the various most important issues, all but foreign policy were statistically significant, most at a high level. Voters who believed that "social security and medicare," the "economy and jobs," and education were the most important issue were significantly more likely to support Clinton. On the other hand, those who believed that taxes or the budget deficit were the most important issue were more likely to support Dole. Voters whose personal finances had improved, or who thought the national economy was much improved, were more likely to support Clinton, as were pro-choice voters. Notice that once we control for all of these different determinants of voter choice, we see little evidence for an independent impact of voter gender.

This does not mean, however, that gender was not a significant factor in voting behaviorDonly that, if it was, it was captured in the attitudes towards different issues. Indeed, we see strong evidence of significant gender-based heterogeneity in the last two columns of Table 2. Some of these differences verify past findings in the literature; women place more weight on the state of the national economy than men, while men and women in 1996 placed roughly equal weight on the state of their personal finances. Women place more weight on education $\square$ which has typically been called a "woman's issue"[while the weights of abortion are almost equivalent between male and female voters. Women also relied more heavily on the importance of the economy and jobs than did men, while men more heavily weighted social security. Last, of importance for our analysis, women weighted tax more heavily in their vote choice as an issue than did men. 
Tables 3 and 4 present the same type of model, but for voter choice in the Senate and House. The general outline of the results in each Congressional election model are very similar to those for the presidential election. While the signs of almost all of the coefficients are the same across these two races for the full sample models, we see that some of the issues are statistically insignificant in each model: "social security and medicare" and foreign policy, for example, are statistically insignificant in the Senate voting model; foreign policy and the budget deficit are statistically insignificant in the House voting model.

Importantly, in both Congressional election models, the tax issue is a strong predictor of voter choice. It is negative and statistically significant in both Tables 3 and 4, implying that voters who thought tax was the most important issue in the 1996 election were significantly more likely to support Republicans. Of even greater importance, we again see the same type of gender differences in the weighting of the tax issue in the Congressional election models that we saw in the presidential vote choice models. In the Senate vote model, while the tax issue is statistically significant in both equations, it is larger for women than for men. In the House vote model, furthermore, the tax issue is statistically significant only for women, for whom it is in fact strongly significant.

In the three different voter choice settings we examined from the 1996 presidential election we thus found systematic evidence for the role of tax as a motivating issue, and we also found that this impact varied by gender. As a matter of ranking, men were far more likely to count tax as the most important issue than were women. All voters who found tax to be the most important issue were significantly more likely to vote Republican than Democratic. Yet among the pool of voters who considered tax to be the most important issue, women were even more likely than men to vote Republican[were more likely, that is, to be affected by their attitudes on tax.

How much more heavily did women weight taxation than men? This is difficult to assess directly from the probit model. Probit estimates cannot be interpreted as easily 
as can simple regression estimates. Such estimates must be translated into probability terms, controlling for all of the other variables in the statistical model.

We present this type of analysis of the effects of the tax issue in Table 5. There we give the probability differences for our full sample, for men and for women, in their voting decisions in each of the three national races. Holding all of the other variables at their sample modal or mean values, we compute the probability that the voter would support a Democratic candidate if she or he did not think of taxes as an important national issue, and then compute this same probability again assuming that they did think of taxes as an important issue. The difference between these two probability estimates gives us a measure of the estimated impact of this issue on voter choice.

\section{< <TABLE 5 NEAR HERE, OR REFER TO APPENDIX>>}

Notice in Table 5 that the tax issue did have a reasonably large impact in the full sample. In the presidential case, if a voter thought of taxes as the most important issue he or she was $15 \%$ less likely to vote Democratic. In the Senate, the same impact was slightly less, with a voter who believed taxes to be an important issue now $13 \%$ less likely to vote Democratic. The impact is even smaller in the House results, with the difference now only being an $11 \%$ reduction in the chances of casting a Democratic vote.

But notice the clear differences between men and women in how strong an impact the tax issue played in their voting decisions in the 1996 election. At the presidential level, the impact of taxes as an issue was 3\% (in absolute numbers) greater for women than for men, 18 to $15 \%$. The result is similar although a bit dampened in the Senate elections, with women again weighing the tax issue $3 \%$ more than men in their voting decisions, 14 to $11 \%$. The difference is the most pronounced in the case of the House elections, where there is a $8 \%$ point difference between men and women, with women weighting the tax issue much more heavily than men by a 15 to $7 \%$ differential. 
While we would again need much further and more nuanced research to pin this effect down, these results might suggest that men are more narrowly strategic in their voting behavior. It is widely thought that voters make decisions in local elections such as House ones looking to the effects on local spending, while deciding national elections such as the Presidential contest looking to general tax and fiscal policyla pattern leading to the phenomena of "ticket splitting" and divided government (see Alvarez and Schousen 1993, Jacobson 1990). Our finding suggests a possible gender dimension to this pattern. Men may be preferring a president who will cut their taxes and a congressperson who will "bring home the bacon," while women are evaluating all candidates by a consistent set of policy preferences. Once again, this would fit in with the general theme of men as egocentric voters, and women as sociotropic ones.

\section{Policy ANalysis ANd Significance}

\section{Substantive Issues in Tax Reform}

Why should we care? The controversy over men's and women's possibly varying preferences in regard to matters of tax has thus far been largely academic, and it has centered on abstract propositions. This is evidenced by the Turnier study, which asked about attitudes toward "tax fairness" or progressivity in general. A gender gap in such matters would suggest that men and women differ in their fundamental conceptions of self-interest, with men being more narrowly and traditionally self-interested, and with women being more altruistic or "compassionate." This is consistent with the "different voice" school of feminism (Gilligan 1982). A gender gap in such attitudes would also suggest that as women began to assert more political power, broad features of the institutional landscapeDsuch as the general level of taxation and the nature of the rate structure $\square$ might change. This possibility seemed to capture an early hope of the feminist movement.

Our central findings suggest that, just as men and women may not differ too greatly in their attitudes towards broad questions of tax, so too might they not differ in their selfinterested orientation, once they confront the same issues. But therein lies the rub: Men 
and women do not always perceive the same issues as being equally important. A more traditional interest group analysis of voting behavior[supplemented by the critical dimension of salience $[$ can thus help to explain the persistent gender-based dimensions of tax policy.

Large tax systems such as the United States has had ever since World War II inevitably involve large choices $\square$ such as over filing units or the deductibility of work-related expenses】that have impacts on family structures and categories of persons sorted by marital and parental status. As noted above, the United States tax system is in many fundamental regards set up to favor more traditional, one-earner households, as opposed to more modern, two-earner ones. The type of detailed issues leading to such biases differ from the broader ones typically discussed in the survey literature. Measuring attitudes about progressivity in the rate structure or the appropriate level of taxation captures general ideological orientation. Thus Turnier and colleagues find, not surprisingly, that a "liberal" orientation is more important than gender in explaining attitudes towards tax "fairness." But it is a different matter to consider more detailed questions of the appropriate filing unit, or the deductibility of child-care expenses, or exemption levels under social security. Here gender might matter more.

A traditional interest group model of politics suggests that working women should favor separate filing, increased child-care deductions, and an exemption level under social security. The salience model suggests that, conditioned on paying attention to tax in the first place, men and women are equally likely to be concerned with their self interest. But women are less likely to find tax issues salient. Our analysis suggests that, if they did, their self-interest might carry over to more specific issues. At the same time, a feedback loop is possible. Given that tax is less salient to women, candidates who are able to target their campaign advertisements or other means of appeal will not focus on women-oriented tax issues, which will continue to suppress their salience.

\section{A Case Study: Marriage Tax Reform at the Millennium}


Quite generally speaking, the United States had a system of separate filing for the income tax until 1948. Under separate filing, men and women file separate tax returns whether married or not, paying taxes on at least earned income under their own, individual rate schedule. A separate filing system, as most developed Western nations now have, is thus "marriage neutral"[marriage is more or less an irrelevance for tax purposes.

In 1948, as part of a large post War "peace dividend," the United States adopted joint filing for married couples (McCaffery 1997, Jones 1988). The initial joint filing rate structure simply doubled the rate brackets in effect for single taxpayers 1 so that the zero and all other rate brackets would extend twice as high for married couples as for single taxpayers. As a result, there were no "marriage penalties," only "marriage bonuses." A couple where each spouse earned the same amount of income would be indifferent to joint filing, since they were in essence doubling their rate brackets by filing separately. In contrast, a couple where one earner was the dominant or exclusive wage earner would see their taxes go down because this dominant earner could take advantage of the wider lower rate brackets.

The 1948 move to joint filing also created a secondary earner bias, however, since a potential second workerDat the margin of the household earning decision】would now enter the income tax rate structure in a rate bracket dictated by the primary earner's salary. This secondary earner bias is conceptually distinct from the question of the marriage penalty, and can be seen as discouraging women's paid work (Leuthold 1984). Indeed, there is evidence that this effect was intentional[that Congress was attracted to a policy that would generate incentives for women to return to the homes that they had left, at least briefly, during World War II (McCaffery 1997).

In 1969, in the face of protests against the "singles penalty"[the precise converse of the "marriage bonus" (by forswearing a possible marriage bonus, high-earning singles could be seen as incurring a penalty)[Congress lowered the rate brackets for joint filing by $20 \%$. The resulting "married filing jointly" rate structure features two potentially 
offsetting effects. On the one hand, married couples receive a benefit of implicit income-splitting, where each spouse is presumed to earn an equal amount, brought about by the fact of joint filing. On the other hand, married couples suffer the detriment of a less favorable rate structure, brought about by the 1969 change. (Because the "married, filing separately" rate structure is set at one-half of the joint filing one, it contains only the detriment of the adverse rates without the benefits of the deemed income-splitting. Separate filing under the current system is thus rarely a viable option, with more than $97 \%$ of married couples[quite rationallyDfiling jointly.) For roughly equal-earner couples, the harms outweigh the benefits, and these couples pay a "marriage penalty." For largely one-earner couples, the converse is true, and these couples continue to receive a benefit or marriage bonus.

By the late 1990s, approximately 50\% of all married couples, consisting of two earners, were paying a marriage penalty. Approximately $40 \%$ of couples, typically consisting of a working man and a stay-at-home woman, were receiving marriage bonuses (Feenberg and Rosen 1995). The prevalence of marriage penalties was directly due to the increase in working married women. Following the inclusion of rather limited marriage penalty relief in the 1994 Contract with America and other events, the "marriage penalty" attained a high degree of political salience in the mid to late 1990s. Stories about the penalty ran on the front pages of major metropolitan newspapers, in leading popular magazines, and on television and talk radio shows across the country.

In this environment, Representatives David McIntosh and Jerry Weller, both Republicans, proposed a "Marriage Tax Elimination Act" in 1997 that would have given couples the option to file separately and singly, as if they were unmarried. Such "optional separate filing" would have eliminated the marriage penalties prevailing under present law while leaving unchanged the marriage bonuses. In other words, it would have helped the $50 \%$ or so of two-earner couples, who would make the election to file separately, but do nothing for the $40 \%$ of one-earner couples benefitting from lower taxes under joint filing. McIntosh-Weller I, as it came to be known, was estimated to cost about $\$ 20$ billion in foregone revenues each year. President Clinton and his fellow 
Democrats failed to endorse the bill, preferring deficit reduction and social spending programs.

Meanwhile, socially conservative Republicans criticized McIntosh-Weller I as not helping one-earner families (see for example Schlafly 1998). Representatives McIntosh and Weller then proposed another Marriage Tax Elimination Act, McIntosh-Weller II. This would expand the marriage "penalty" relief to all married couples by doubling the rate brackets】that is, it would be a return to 1948-style rate brackets. McIntosh-Weller II differed from McIntosh-Weller I principally by increasing marriage bonuses for oneearner couples; equal-earner couples were treated the same under the two versions. Republicans thus responded to Democratic inertia on the first version of marriage penalty relief by upping the stakes; McIntosh-Weller II was estimated to cost $\$ 30$ billion a year.

The saga of marriage penalty relief nicely illustrates the practical effects of the divergent salience of tax reduction for men and women. Whereas McIntosh-Weller I ought to have appealed to working women as lowering the secondary earner bias and the taxes facing two-earner couples, this traditionally Democratic constituency preferred using the money for general social spending. Left on their own to formulate taxreduction plans, Republicans increased the stakes by widening their proposal to include all married couples, most notably including the more traditional, single-earner families at the center of the contemporary social conservative movement. Because taxes matter more to the core Republican constituency, the form of tax relief gets shaped by traditionally conservative preferences, even where the provisions at issue have deep impacts on traditionally liberal and feminist concerns and constituencies.

\section{Prospects for Change}

Our central thesis is that men and women do not differ significantly in their first order preferences towards tax or, presumably, in their self-interested orientation, once the same issue is joined. Men and women do seem to differ, however, in the second order weighting or ranking of their primary preferences, with men putting more emphasis on 
tax than women do. All of this plays out against a background fact of structural gender biases in the law.

If our analysis of political behavior is correct $\square$ we conclude by stressing the need for more research and analysis $\square$ the possibilities for effecting tax law change to help modern working women lie in two directions. One is through attaching greater salience of tax issues for women. In one way or another, women and feminists generally would have to pay more attention to tax $\square$ would have to weight the issues of tax more heavily in their political behavior. This change involves a reordering of private preferences.

A second possibility for change lies in reforming institutional mechanisms so that tax rules can be promulgated independent of other issues, for the pairing of tax with other issues can be seen to contribute to the gender bias of the law. Voting rules that allowed for separate input on discrete policy issues would make more manifest the underlying first order preferences of the voters. This change would not involve any change or reordering of private preferences; it would simply allow those preferences that already exist but can be hidden by a second-order weighting procedure to come out.

\section{CONCLUSIONS AND SUGGESTIONS FOR FURTHER RESEARCH}

There is more research that needs to be undertaken to explore the basic findings presented in this chapter: one, men and women do not differ significantly in their primary preferences over matters of tax and, two, that they do differ in their secondary ranking of these preferences. Only by a much more thorough analysis of the ways in which tax issues play out in electoral politics in the United States can we better understand the persistence of significant gender biases in tax policy in recent decades. At this point in our research, we do know that these gender biases in tax policy exist and that women and men place different weight on tax issues when making candidate choices in national elections. 
The next stages in this research agenda must take two different paths. The first is to explore more directly the relative salience of tax issues for men and women through additional studies of existing survey and public opinion data. Are the differences in opinions and decisions we have found a persistent attribute of American politics? Have men and women consistently in recent decades thought the same or differently about tax issues? There simply has been little research on this important question.

The second direction of research is to gain a better understanding of how tax issues are being raised and discussed by political leaders and elites. How are these leaders and politicians framing tax issues? Do they evoke different frames for men and women? Is this at least partially the source of gender differences in opinions about taxation? Can political elites and candidates produce "gender gaps" in opinions about tax policy? Again, there has been little research conducted on how politicians and elites politicize tax issues along gender lines. As in many other aspects of gender and politics and our understanding of their relationships, it is time for change. 


\section{BIBLIOGRAPHY}

Alvarez, Michael and Schousen, Matthew. 1993. "Policy Moderation or Conflicting Expectations: Testing the Intentional Models of Split Ticket Voting." American Politics Quarterly 21:410-438.

Chaney, Carol Kennedy; Alvarez, R. Michael; and Nagler, Jonathan. 1998.

"Explaining the Gender Gap in U.S. Presidential Elections, 1980-1992."

Political Research Quarterly 51:311-340.

Feenberg, Daniel R and Rosen, Harvey S. 1995. "Recent Developments in the Marriage Tax." National Tax Journal 48:91-101.

Gilligan, Carol. 1982. In a Different Voice: Psychological Theory and Women's Development. Cambridge, MA: Harvard University Press.

Goldin, Claudia. 1990. Understanding the Gender Gap: An Economic History of American Women. Cambridge, MA: Harvard University Press.

Hanson, Sandra L., and Ooms, Theodora. 1991. "The Economic Costs and Rewards of Two-Earner, Two-Parent Families." Journal of Marriage and the Family 53: 622-34.

Hite, Peggy A., and Roberts, Michael L. 1991. "An Experimental Investigation of Taxpayer Judgments on Rate Structure in the Individual Income Tax System." Journal of the American Taxation Association 13:47-63.

Jacobson, Gary C. 1990. The Electoral Origins of Divided Government: Competition in U.S. House Elections, 1946-1988. Boulder, CO: Westview Press. 
Jones, Carolyn C. 1988. "Split Income and Separate Spheres: Tax Law and Gender Roles in the 1940s." Law and History Review 6:259-310.

Kahneman, Daniel, and Tversky, Amos. 1979. "Prospect Theory: An Analysis of Decision Under Risk." Econometrica 47:263-291.

Kornhauser, Marjorie E. 1997. "What Do Women Want? Feminism and the Progressive Income Tax." American University Law Review 47:151-163.

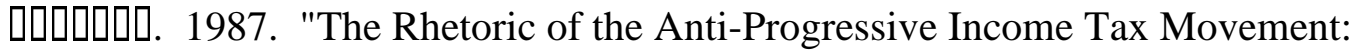
A Typical Male Reaction." Michigan Law Review 86: 465-523.

Leuthold, Jane H. 1984. "Income Splitting and Women's Labor-Force Participation." Industrial and Labor Relations Review 38:98-105.

Mattei, Laura Winsky, and Franco Mattei. 1998. "If Men Stayed Home . . . The Gender Gap in Recent Congressional Elections." Political Research Quarterly 51: 411-36.

McCaffery, Edward J. 1997. Taxing Women. Chicago, IL: U. Chicago Press.

Roberts, Michael L., and Hite, Peggy A. 1994. "Progressive Taxation, Fairness, and Compliance." Law \& Policy 16:27-48.

Schlafy, Phyllis. 1998. "Watch out for Marriage Tax Reform." Available from http://www.eagleforum.org. February 4, 1998 [cited November 1, 1998].

Turnier, William J.; Conover, Pamela Johnston; and Lowery, David. 1996. "Redistributive Justice and Cultural Feminism." American University Law Review 45: 1275-1322. 
U.S. Department of Commerce. U.S. Bureau of the Census. 1998. Statistical Abstract of the United States, 118th Edition. Washington, D.C.: GPO.

Welch, Susan, and John Hibbing. 1992. "Financial Conditions, Gender and Voting in American National Elections." American Politics Quarterly 21:343-59. 


\section{ENDNOTES}

1. There is a large literature on the gender gap in American national elections. See Chaney et al 1998 and Mattei and Mattei 1998 for helpful summaries.

2. McCaffery 1997 contains much of the relevant historical background. The principal features in the pattern of gender bias are the provision of spousal benefits under Social security, put into law in 1939 (see Chapter Four); joint filing under the income tax, put in effect in 1948 (Chapter Three); and the refusal to systematically treat child-care expenses as tax-deductible business ones, beginning with a judicial decision in 1939 (Chapter Five).

3. See Goldin 1990 and U.S. Department of Commerce 1998 for relevant statistics. 